\title{
Processing the difference: Spanish-language media in Morocco
}

\author{
Frank Jablonka
}

University of Vienna, Inst. For Romance Languages and Literatures \& University of Picardy, Amiens, LESCLAP frank.jablonka@univie.ac.at // fjab@gmx.net

\begin{abstract}
According to the sociological theory of systems ( $N$. Luhmann), social systems, such as media systems, organize their cognitive and communicative operations on the basis of a set of "guiding differences". In Luhmann's approach, the differences that give the functional and operative orientation to the system are contingent. Following Edward Said's postcolonial studies, the analysis of Moroccan blogs in Spanish shows that these "guiding differences" are not contingent: they are rooted in the colonial and postcolonial history and depend on various parameters (geographical, socioeconomic, cultural, sociolinguistic, etc.). In this paper, we analyze the communicative and symbolic procedures in blogs emanating from different (especially urban) sites situated inside and outside the former Moroccan Spanish colonial area and the urban enclaves still belonging to Spain (Ceuta, Oujda, Sidi Ifni, Sahara / Laâyoune). With regard to the "guiding differences", we can point out that the North is the conservative pole, whereas our analysis reveal a deconstructive evolution the farther we go to the South in the virtual mediatic space. From a semiotic point of view of the contact of postcolonial symbolic codes, we are able to conclude that if, according to McLuhan, the medium is the message, we have to emphasize that first of all the medium's code is the message.
\end{abstract}

\section{Indexing terms/Keywords}

Constructivism - Media - Postcolonial language - Social system theory

\section{Academic Discipline And Sub-Disciplines}

Sociolinguistics \& Discourse Analysis of Media (Spanish)

\section{SUBJECT CLASSIFICATION}

Discourse analysis of contemporary media in Morocco (Spanish)

\section{TYPE (METHOD/APPROACH)}

Semiotic image-text analysis

\section{Council for Innovative Research}

Peer Review Research Publishing System

\section{Journal: Journal of Advances in Linguistics}

Vol 3, No. 2 


\section{INTRODUCTION}

Spanish-language media in Morocco represent currently an almost unexplored field of research. The present contribution is centred on some aspects of postcolonial (and even, in a large sense, "colonial", since we take into account online documents from the Spanish "presidios" on the Mediterranean coast as well) discours formations in the Spanish-language "blogosphere". While discourses focused on postcolonial topics in French blogs have already been analyzed (Torterat, forthcoming 2013), investigations of a similar orientation do not seem to have been carried out on our research object.

This first analytical approximation to this topic is based on the Siegen School approach of constructivist semiology related to media communication (Schmidt 1992, 1994), as well as on the sociological theory of systems developed by Niklas Luhmann (1988, 2009; cf. also Fuchs 2004, Berghaus 2011). Our procedure consists essentially in the analysis of different ways of processing the "leading differences"1 in the sense of Luhmann's system theory. Given that constructivist approaches to media have been worked out for modern Western societies subjected to a functional differentiation into subsystems, coded by binary oppositions in the form of "leading differences", we have to consider that these "codes" are different in the Moroccan society, the latter not being exposed in the same way to mass media communication and subjected to functional differentiation (even if these processes go crescendo). However, tools of discourse analysis turn out to be indispensable and useful as an organic complement to constructivist systemic approaches for clarifying the functioning of media communication in the North African Hispanic "blogosphere". We will make explicit our theretical and methodological approach in the first part of the present article.

\section{THEORETICAL ISSUES: “ORIENTALISM” AND CONSTRUCTIVISM}

The importance of this discursive issue comes immediately clear if we consider that the object of our analysis is an aspect of what is currently labeled, since Edward Said (1978), Orientalism. There is, a priori, no doubt about Morocco's belonging to the "Orient"; however, this categorization is not due to geographic criteria. It is easy to show that the Moroccan territory is in part located further west than the Iberian Peninsula. So, if we categorize the field of the media we are investigating as "Oriental", this identification is the echo of a discursive formation whose agents are principally "Western" authors. This formation is integrated into a structure of domination of the Western metropoles over their territories, population, cultures and languages. This structure, and this discourse are, of course, rooted in the colonial era, but they are still impacting the postcolonial context. The concept of "Orient" appears to be a discursively constructed idea - principally in intellectual discourses - and shaped in accordance to the relations of power. It represents from the beginning a conceptual tool at the ideological front of colonial, and then postcolonial conflicts, for the purpose of the stabilization of power in the hands of the "Western" élites, and later in those of assimilated local leading groups. It is important to understand that "Orient" as a power-loaded discursive construction and conceptual tool has torn the intellectual élites in the former colonies (today's postcolonies) into its ideological field of gravitation. We find its almost 'natural' prolongation in (more or less) scholarly discourses articulated especially in the media. This conceptual and ideological transmission becomes doubly virulent (and interessant to analyse) when the articulation is effected in one of the former colonial languages - here in Spanish.

\subsection{The constructivist and systemic approaches}

Our emphasis on the constructive character of such a central category as "Orient" allows us to integrate the concept into the theoretical and methodological orientation which gives us the necessary analytic frame for the Spanish-language media discourses in Morocco (and in the "presidios" Ceuta and Melilla ${ }^{2}$ ): constructivism (in its "radical" form - cf. the titles of S.J. Schmidt quoted in bibliography), together with Luhmann's theory of social systems. The central idea of this approach is that we construct the world in which we live by living together in it. The Alpha and Omega of this construction are perception, experience, and communication. If the - our - world is rooted in observation and the observer of society (starting with the immediate social environment), it is because observation and the observer create by means of these operations, hence autoreferentially, those entities which became accessible and communicable to consciousness, i.e. facts. By virtue of this systemic autoreferentiality, the organizational logic and the principles of the constructive processes are reproduced, stabilized and perpetuated in their structure, and the systems are able to effect operations of observation and cognition.

According to Luhmann's (1988) approach based on George Spencer Brown's (2008) logic of Laws of Form, the starting point of a system in statu nascendi is a diffuse and amorphe "unmarked space". The first imperative: " Draw a distinction ", drives the emerging system to the first fundamental division by tracing the first significative mark. The system draws a difference between something (itself) and something other (its environment). This fundamental distinction is in Luhmann's approach completely contingent. The underlying criteria and the eventual motivations (sociohistorical, political, cultural, linguistic etc.) are only taken into account to the extent that they could have been others. These can be identified as the "leading differences" in which the fundamental "code" of the system is grounded. What the system recognizes as being itself, respectively as being something other than itself, as well as the internal functional logic and the constructive principles to which its operations (observation, cognition, communication ...) is subjected to this first fundamental division. From this starting point of view, the system observes what seems to it to be his environment and the primordial mark which separates it from his environment. By way of the operations of observation and cognition, the excluded entities (the mark, the external world) are copied into the internal structure of the system ("reentry"). These two entities, together with the system's perception of itself (its "identity"), come into play for the second time, and this "reentry" is effected according

\footnotetext{
1 This is one of the current English translations of the German term "Leitdifferenzen" (plural), another English expression is "operative distinctions". For the explanation see the first part of the present paper.

2 The present paper takes into account Ceuta, but not Melilla.
} 
to the functional logic and the system's internal constructive principles, the first exclusion of the latter representing their first condition of possibility. In respect of media systems, and especially of those which are objects of our observation, this relation appears in the form of a principle of fundamental reflexivity where the Same and the Other meet as two poles of one and the same gestalt.

\section{2. "Leading differences"}

The "leading differences" which are central in our epistemological frame are extremely similar to the basic oppositive structure of binary codes. This is one of the aspects, perhaps the most fundamental one, where the structuralist heritage of Luhmann's system theory becomes visible. ${ }^{3}$ To understand the theory of society and of the media in Luhmann's systemic approach, to the extent it is useful for the application to our field of investigation, we have to insist on the functional differenciation of society into subsystems which are all coded following binary categories (the "leading differences"): law (just vs. unjust), science (true vs. false), esthetics (beautiful vs. ugly), ethics (good vs. bad), economy (payment vs. non-payment), etc. Luhmann is, of course, principally interested in the European societies, and generally of the Western type, but there is no doubt that in the models of society of the emergent countries (such as Morocco), the functional differentiation becomes more and more important as well.

In the Western world, and especially in Europe, the opposition between Christianity and the non-christian area (especially Islam, during almost one millenary and a half of continuous frictions, but also Judaism), and more globally, Western world vs. Orient has been chrystallized as the 'archetypal' "leading difference"; this opposition was paroxystic during the colonial era and the emergence of "Orientalism", convincingly analyzed in Edward Said's writings, and is prolonged during the postcolonial era until today. We are hence in the position to identify the "leading differences" to which the basic functioning of the Northern African media systems which represent the object of the present observation and investigation are subjected, both in Morocco's postcolonial Hispanity and in the Spanish "presidios". However, this basic binarism has grown some more complex, as the difference between Western World and "Orient" has been amplified by the opposition North vs. South. Without any risk of banalisation by abusive reduction of complexity, we can identify the two terms of the "leading difference" to which the media are subjected and which constitute two opposite blocks [North/Europe/Western world/ 'Christianity'] vs. [South/Africa + Arabic world/Orient//slam]

\subsection{Colonial and postcolonial issues of "leading differences"}

In spite of our above affirmation (cf. § 1.2.) that the societies in the emerging countries are also torn into the general process of functional differenciation into subsystems, in Morocco persists a dominant code which tends to superpose itself upon all the others, imposing them its logic: religion. In Morocco, Islam penetrates all the spheres of the personal and social life, including law, politics, education - and the media. ${ }^{5}$ The question is certainly not principally situated on the theological level, but it represents undodubtedly the first ethnocultural category of distinction and identity demarcation vis-à-vis Christianity, i.e. the so-called "christian" Western world. Morocco represents obviously a particularly fertile humus for evolutions of Edward Said's concept of "Orientalism". It looks like the other components of the block of "leading differences" North vs. South, Europe vs. Africa + Arabic world, Orient vs. Occident - are largely derivated from the binarily codified distinction "Islamic" vs. "non-Islamic". It is nevertheless clear that the central 'non-Islamic' term is 'Christianity'; this is understandable on the background of a conflictual history since (at least) 711 . This history remains deeply etched in the collective memory on both sides, but is has been superposed by the colonial history (in Spain already by the Reconquista) with undisputedly virulent consequences. In addition to that, this complex is amalgamated with geographic categories at the crossroads of the interfaces "East/West" and "North/South". This imbrication is even more immediately striking when whe take into account the Hispano-Moroccan territorial conflicts which remain still unresolved, most notably the West Sahara (i.e. Moroccan Sahara) conflict, but also the problem of the enclaves ("occupied territories" from the Moroccan point of view) on the Mediterranean coast, principally the towns of Ceuta and Melilla, ${ }^{6}$ without forgetting the retarded recuperation of Ifni (the cases of Tangier and Tarfaya should also be mentioned). In addition to this, it is necessary to take into account the migratory movements between the southern and the northern Mediterranian coast. This is a first-order epicenter of conflict between Spain and Morocco, the only Arabic and African country with which a member state of the European Union shares a land border. In conditions of globalization, however, these differential factors are superposed and partly adjusted by the constraints of economic cooperation and the creation of an appropriate administrative framework; this leaves non-negligeable impacts on the operations by which the difference is processed in the media.

\subsection{Morocco: a "media society"?}

If perception and cognition are subjected to communicative functions, and if communication is processed via different sorts of (today primarily electronic) media, we must keep in mind that Morocco is not a "media society" in the same way as the societies of the European countries (or, more generally, those of the "developed" Western type). Plain participation in mass media communication presupposes alphabetization in at least one European language (and / or in Standard Arabic)

\footnotetext{
${ }^{3}$ Luhmann's system theory is nevertheless considered to represent one of the poststructuralist branches.

${ }^{4}$ Christianity appears here in inverted commas because of the advanced process of secularization, even in Spain, but the religious motivation persists, of course, under cover of socio-identitary and cultural crypto-categories. The situation is very different in the Islamic world.

${ }^{5}$ Even if Islam does not impact significatively on the Moroccan documents we have selected for this analysis (except Sidi Ifni, Annex 3).

${ }^{6}$ Neither the Perejil Island nor the other disputed rocks ad islands are to be discussed in the present article.
} 
In Morocco, alphabetization is still far from being generalized, especially in the rural zones, and very hard to quantify, even if the progress in the younger generation is undeniable.

Knowing this, orientations of value, behavior and acting are to be characterized as mediatic constructions. Media play a decisive role in what is considered and accepted in a community as being (ontologically) "real" and (normatively) "correct". The "coding" explicitated above (cf. §§ 1.2., 1.3.) has here a key function. An inter and retroactive process is established: on the one hand, the media use the reservoir of preexisting cultural (and generally symbolic) codes, on the other hand they act on the latter and participate hence in their transformation. This explains the media's central and fundamental role in the transition of cultural orientations typical in traditional societies to those which characterize the modern informational societies. This is the process to be observed in vivo in emerging countries like Morocco (cf. Bennani-Chraïbi 1994; cf. also Jablonka 2009). The use of colonial (or ex-/postcolonial) languages like Spanish can be considered the enterance door for the influence of "Western" categories and participate in the restructuration of preexisting cultural codes with affinities to the territorial languages.

\section{DATA ANALYSIS}

These theoretical considerations are useful as a basis for the analysis of several online-documents to be found on websites of organizations located in different areas of North-Western Africa's Hispanity. The consideration of the sociohistorical, political and ethno-sociolinguistic contexts, which differ from one case to the other, will allow us to observe and to analyze the organization and the reorganization of binary codes in terms of "leading differences". This contextualization will permit us to reformulate the notion of contingency of the systemic organization and of the "codes" to which the systemic logic is subjected in dependence on the fundamental significative distinctions, and to show its relativity vis-à-vis the underlying social parameters. A virtual movement in the mediatic space will give us access to this comparative perspective: our starting point will be the extreme North-West (Ceuta / سد ب تد - Annex 1), and we will arrive in the extreme

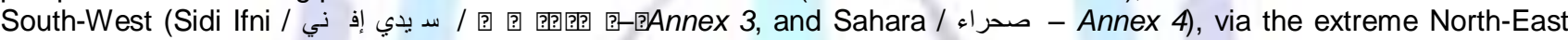
(Oujda / وجدة - Annex 2).

\subsection{Ceuta}

In the first analyzed document available online on the "Blog de Ceuta 2" it appears immediately that the "archetypal" binary opposition (cf. $\S 1.2$.) organizing the document's structure is conserved and medialized in its pure and nuclear state. According to this logic, the two urban "presidios" ("Ceuta y Melilla") are threatened by the Arabic world ("amenaza islamista"). This threat is not limited to the Spanish enclaves in Northern Africa; the "presidios" appear only inasmuch as their represent the extreme extension of the European (or even Western) domain, exposed in its entirety to the Islamic threat ("la amenaza del mundo islámico contra occidente' en Europa"). Following the logic of this construction, Ceuta's and Melilla's belonging to Europe, despite their geographic localization in Africa, is evident and uncontested. Obviously, the system does not function in dependence to geographic distinctions; these ones are insignificant in the internal functional logic. The operative distinctions are to be identified on the political level; they follow the essentialist logic of civilizational areas in an irreconcilable perspective of confrontation.

The threat appears even more real and virulent as it is to be identified inside the army itself. Hence, we are in presence of the construction of a scenario in which one oppositive pole susceptible to be dominated (Oriental, African, Arabo-Islamic, the South) is starting (again) to invade the other (European, Spanish, Western, christian, the North), susceptible to keep its dominating position; what is constructed seems to be a sort of invasion from inside by foreign elements having infiltrated the army ("peligro de la infiltración de islamistas"). Inasmuch as this "infiltration" is put in relation to the islamist attentats in Spain ("'posibles atentados en Europa"), where the memory of the events in Madrid railway is still fresh, the danger appears to be real ("'Es un peligro real y cierto"'), going far beyond Spain and concerning also its Wesern partners ("las autoridades estadounidenses como las francesas han advertido", "incluyo Portugal").

In this perspective, the specter of Al-Andalus ("'evitar otra reconquista' musulmana del territorio español") appears with a compelling logic; the conquest of Ceuta and Melilla being the historical prolongation of Reconquista in the African territory, the construction of the threat is extended from the enclaves all over the Iberian Peninsula ("'Al Andalus es toda la Península Ibérica" y por tanto la consideran "territorio ocupado"'”). We can observe the observation operated by the mediatic system of Ceuta onto its extrasystemic environment, i.e. the Marrocan Other; following the categorization perceived by the Ceuta medium, this Other constructs the enclaves as "occupied territories". In this binary construction, we can see in the attribution of the perception of volitive operations to the opponent the reflex of first-order identitary issues: the very hotspot is Spain's national identity, the 'grand narrative' of Reconquista representing Spain's foundational myth (Delmote 2001). Obviously, from the point of view of the principles of its internal functioning, the system makes sure its own identity by the attribution of states and representations to its extrasystemic environment. This could be interpreted as a symptom of destabilization of the system's dominant code; the consequence is a certain hardening of the categorization which is reflected by an extremely martial language ("amenaza", "tremendas cautelas"), which articulates perfectly with the belligerent iconic message. From this point of view, it is easy to understand the Cold War rhetoric in this document ("quinta columna"; "lo malo"). The end of the East-West confrontation in the early nineties has left room for a new fundamental opposition, i.e. North-South, which has revivified the former construction of the Islamic problem. Even if Christianity is not explicitly mentioned, it is nevertheless evident that we are in presence of a confrontation in terms of partly secularized religious crypto-categories (at least on the part of Spain / Europe, cf. footnote 4), extremely virulent in identitary and civilizational terms ("'superponer la condición por sentimiento religioso a su obediencia a las leyes de la nación a la cual han 
prometido o jurado,."7) We can easily identify the sources of destabilization of the ancient codes in this recent historical evolution. In other cases analyzed in the present paper we will be able to show different evolutions of the oppositive lines of "leading differences". In the case of the Ceuta document, the evolution tends to a hardening, even to an excessive overstatement of the "archetypal" binary structure.

Table 1. Ceuta: Coded oppositive structure in terms of "leading differences"

\begin{tabular}{|c|c|c|}
\hline Orient, Arabo-Islamic world & $\begin{array}{l}\text { VERSUS (hard- } \\
\text { coded binarism) }\end{array}$ & $\begin{array}{l}\text { Western world (including Europe (including } \\
\text { Spain) (including Ceuta/Melilla))) }\end{array}$ \\
\hline $\begin{array}{l}\text { militares extranjeros y particularmente de } \\
\text { religión musulmana } \\
\text { otra reconquista musulmana } \\
\text { quinta columna (= inner enemy, alien } \\
\text { element) } \\
\text { insurgente "chofer del jefe" de la Policía } \\
\text { afgana } \\
\text { condición por sentimiento religioso } \\
\text { islamistas radicales creen que Al Anda- } \\
\text { lus } \\
\text { "territorio ocupado" } \\
\text { posibles atentados }\end{array}$ & & $\begin{array}{l}\text { del territorio español } \\
\text { en el Ejército español } \\
\text { dos guardias civiles y de su traductor } \\
\text { obediencia a las leyes de la nación a la } \\
\text { cual han prometido o jurado } \\
\text { es toda la Península lbérica } \\
\text { en Europa }\end{array}$ \\
\hline
\end{tabular}

\subsection{Oujda}

The Oujda online document (Annex 2) appears to confirm a general tendency: the farer we move to the East along the Moroccan Mediterranean coast, inside or outside the former Spanish Protectorate territory, and hence the farer we get from the geographic space of Europe, the more the African perspective becomes dominant. But it is still (and not accidentally) in Spanish, and there seems to be a link between the African perspective, from the Moroccan viewpoint, and the choice of Spanish. Because even if Oujda, the major border town to Algeria, is located outside the former Spanish Protectorate zone, it represents an obligatory step for the Subsaharian migratory movements bound to Melilla via Algeria; this is undoubtedly one of the key factors for the diffusion of Spanish into the border zone: "Ujda está a sólo unos 150 kilómetros de la ciudad costera de Melilla", and this proximity represents an important factor in a context of almost generalized mobility.

On this background, the iconico-textual link is extremely revealing. The official closure of the Algero-Moroccan border motivated by the (partly military) tensions between the two countries, especially due to the Sahara conflict, does not represent any major obstacle to the numerous clandestine migrants. The photo shows a clandestine Subsaharian migrant in the middle of the no mans's land of the desert border region; the bullets in the migrant's hand give an account of this conflict. Hence, the migrants find themselves trapped 'between the fronts'; the choice of Spanish indicates that this border represents the dividing line where begins the gravitational field of European civilization, which is first of all Spanish-speaking, because the starting point of the passage to the European continent is unevitably Melilla (or otherwise Ceuta), and Spain is the first destination in this "tierra prometida de Europa". The 'real' Africa lies beyond this grey area along the border, as indicated by the presence of the black migrant, while Oujda is the first step into an intermediate, premonitory, preEuropean world, a potential 'pre-Promised Land'. The principal bone of contention between the two enemy brothers which has led, to a certain extent, to the characteristics of the Algero-Moroccan border being the Sahara problem, this border and Algeria are inescapably driven into a logic of categorization linked to the African context, while removing from Europe: "ubicación estratégica en la vía migratoria que cruza a través del Sáhara hasta Malí, Níger, Nigeria e incluso más allá". It is hence evident that even Sahara is included in the African pole opposed to Europe, while for Morocco (without Sahara), here represented by Oujda, this inclusive-exclusive relation is less evident, from the point of view of the logic of this perceptive functioning. This logic situates Morocco still in Africa, but confers it a special, privileged status. While the binarism remains substantially hard-coded ("los sueños de los inmigrantes se topan con la implacable maquinaria de la Fortaleza Europa"), it is clear that this rigid binarism opens up only a privileged line of sight, provided that there is a shared border

\footnotetext{
${ }^{7}$ Note the celebrative language in this national rhetoric with the sacrament of oath which, from a systemic point of vue functioning according to a different logic of binary differentiation, could easily be seen as a sacrilege.
} 
(especially land border) with a European country - and Morocco is the only African (and Arabic) country in this case: at the enclaves (Melilla and Ceuta). By virtue of this categorization, Morocco range tendentially in the same category as the Subsaharian migrants, because they are subjected to one and the same problematic generated, as it seems, by the European oppositive pole. It is a virtual war: on the one hand, the Algero-Moroccan border is mentioned without any allusion to the armed conflicts between the two countries; on the other hand, the territorial problem with Europe is presented side by side with the border problematic which divides Algeria and Morocco, this time with a martial rhetoric: "frontera argelina en las guerras fronterizas de Europa". We can conclude that the real desert of no man's land along the border the migrants are supposed to cross, and where they have to look out at bullets and other violent dangers, is the one between Europe and the African continent. This is the hidden - the underlying 'real' message of the iconic element. But we cannot see how an African system other than Moroccan - especially in the North and in proximity to the enclaves - should be able to effect such operations of perception, of judgement, of categorization and of communication.

However, we must note that the border between the European and the African pole appears to be defined in all its harshness from the European viewpoint. This attribution obeys to the internal logic of Oujda's mediatic system (oppositive African pole), but it is assigned to the external systemic environment (oppositive European pole = construction from the viewpoint of the further one and integrated into it as a copy). The border appears hence twice: the first time as being traced by the system (which constructs this notion of border following its internal logic as ideally permeable); the second time as a copy of the notion of border defined as impermeable, following the logic of the extrasystemic environment constructed according to the logic of the intrasystemic perceptive and cognitive functioning. This double occurrence of the notion of border, and their diametrically opposed definitions are the very core of the scandal mediatized and communicated in this online document. From the "Third World" viewpoint of the Moroccan medium, the "First (i.e. European) World" is self-sufficient and can hence easily exclude the "Third World"; by contrast, the Moroccan (and generally African) differential pole appears to be not entitled to claim the same self-sufficiency. In linguistic terms, the absence of selfsufficiency is reflected in the asymmetrical use of the other's language. The use of Spanish is here to be identified as an expansive, or even transgressive strategy: as the symbolic occupation, or even appropriation of a part of the other's territory. The Same is intended to assimilate its Other. This operation represents semiotically the South-North migratory movement (and its legitimity) to Europe, to Spain, via the "presidios" (here Melilla). This procedure corresponds to an operation defining the qualities of permeability and porosity of the deviding line as necessary, for the blocking is at the origin of numerous problems on the side of Morocco, as represented in the Oujda document, which explains the absence of internal self-sufficiency. From the standpoint of the logic of this mediatic system's internal functioning, the postulate of permeability of the border between the Same and its Other is a must. To the extent as this permeability is refuted by the extrasystemic environment (appearing as a copy integrated into the system), the conflictual tension between the two differential poles is undergoing a considerable heating up of the communicative climate; this communicational climate change seems to articulate itself preferentially in the impossible choice of non-communication, as it appears in this media document: "pero Europa guarda silencio".

It appears, in quintessence, that the oppositive binarism remains in Oujda nearly as rigidly coded as in Ceuta, given Morocco's tendentially somehow intermediate position between Africa and Europe. But substantially, in this North-South interface which the Mediteranean coast represents, the "archetypal" binarism remains deeply and symmetrically preserved in spite of the surface differences and divergent communicative functions. The evolution is rather slight. Our task is now to observe if the situation is comparable in the southern part of Morroccan Hispanity.

\subsection{Sidi Ifni}

A glance on the website "El Rincón de Sidi Ifni", starting with the header bar, should be sufficient to convince ourselves that the oppositive structure of the "leading differences" is subjected to an important deconstructive evolution. We can affirm the convergence of the two oppositive poles, i.e. Oriental [Arabic (+ Berber)] vs. Western (here Spanish) by virtue of symbolic blending procedures. The motto which appears in the lower part of the heading bar - "Una mirada al pasado, sin perder de vista el futuro." - turns out to be programmatic for the deconstructive procedure of the pattern of the "leading differences": the recourse to the collective historical memory opens up the view on the future. In a historical framework where the ambivalence of occidentalization is affirmed, Spain and Spanish are revalued as attractor poles of occidenttalization. In semiotic terms, this procedure necessitates the harmonization, if not the synthesis of the oppositive terms. The detail analysis shows effectively the reconstruction via deconstruction of history by the recourse to the conflictual sources of the collective memory in order to use the symbolic ressources with the aim of a convergence.

In a first step, we will direct our analytic regard towards the writing. The writing is obviously Spanish, and in Latin characters. No Arabic (neither Tifinagh) character appears. Nonetheless, the writing underwent an Arabic (or, more generally, oriental) stylization. The Latin characters $S$ and primarily $d$ resemble to lām (J); Latin $c$ looks like inverted dāl (د). Furthermore, dots are added above some characters. The dots on the $i$ are substituted by diaeresis ( $i)$; hence, the Latin character looks like Arabic tā (ت, or better $)$. One dot is added on the right part of the characters $e$ and $n$ in such way that they remind us the Arabic character nūn (ن, or better $\dot{\text { ) }}$. Independently to this, the added elements do not have any diacritic function in the Latin graphic system. In the Spanish graphic code, $i$ and $\ddot{i}$ can, of course, be considerd allographs (combinatory variants); but in the position in which the second dot on the $i$ appears in this header bar, its distinctive value is none. In the same way, the dots added above the right parts of $e$ and $n$ do not add any graphematic value: from the standpoint of the Spanish graphic code, they are simply redundant. These alterations impact certainly the graphic configuration, but they do not have any graphematic incidence. They are in no way situated on the denotative, but only on the connotative level. We are hence not in presence of a code interference, but of the superposition of two distinct codes which remain clearly identifiable in their individuality: the Latin, i.e. Spanish graphic code (Western differential pole) is superposed by another, 
an esthetic code; this code is marked by Arabic, or more generally Oriental imprints, but remains distinguishable from the former.

This second Arabic, or Oriental code which has affected the graphic configuration is integrated into the global semiotic structure of the header bar. The white silhouette of a mosque with the minaret in the middle, on an azure ground, is clearly to be identified. Hence, the reference to the Arabo-Islamic heritage remains, in semiotic terms, central, as indicated by the graphic disposition. The same applies to the camel on the sand-colourd crescent moon (like the writing), which reminds us the caravans crossing the desert; the deeply rooted lunar character of the Arabo-Islamic civilization has also to be taken into account (see, for example, the Hegirian calendar). In Sidi Ifni, the reference to the desert is most immediate, for this town being considered the Atlantic door to Sahara. ${ }^{8}$ The left part of the header line articulates perfectly with the right part, where we can see a veiled person in traditional bedouine style desert clothes. These clothes seem to refer to the local berber textile folklore. This is, in semiotic terms, a strong identity message: the Sidi Ifni region is located right within the ethno-dialectal Tashelhit area. ${ }^{9}$ Sidi Ifni is named after a homonymous local Berber saint (marabout). It is also known that Berberity (confederation of Aït Baâmrane) played a most important identity role in the colonial and independentist conflicts against the Spanish occupiers and exerted an extraordinarily powerful resistance, especially during the thirteen additional years of the colonial era in this region after Morocco's national independence. ${ }^{10}$ A spiritual component evoking popular Islamic currents related to the collective memory of the history of the very conflictual colonial relations with the Hispanic world is also integrated into the identity message. It is to be noted that the only exposed part of the veiled body are the eyes. The semiotic message is clearly centred on the visual level and articulates with the motto that orients programmatically the present media system, written in Spanish in caracters without any Oriental mark, linked to the text whose graphic properties do not differ in anything from a European / Western textual message in standard Spanish: "Una mirada al pasado, sin perder de vista el futuro." Our semiotic analysis shows that this motto is programmatically realized, from the heading bar on, announcing the mediatic procedure to which the online documents are subjected.

Hence, the iconico-textual articulation gives us access to a double vision (interplay past $\leftrightarrow$ future) which lets the observer perceive the accent put on the cultural and symbolic Arabo-Islamic heritage in a Spanish textual environment; this allows us to affirm the reconstruction via deconstruction of "Oriental" identity. We are not in presence of a "métissage" but, in Jean-Loup Amselle's (2001) terminology, of a "branchement" ['pluging']. These two procedures lead both to the emergence of communicational and symbolic phenomena sui generis in the field of language and culture contacts. But whereas in "métissage" the cultural (and / or linguistic) entities are blended with one another, in "branchement" the components in contact remain identifiable in their individuality: "pas de culture sans cultures" (ibid., p. 14) - and, mutatis mutandis: no language without languages, and no code without codes. According to our semiotic analysis, this is exactly what is going on in Sidi Ifni, which explanes the polyphonic articulation of the global message. The terme "branchement" allows the conceptualization of the reflexive and constructive character of the identity issues. Amselle (ibid., p. 9) emphasizes that the best way to back up - or (re)define - one's identity is the reflection in the Other. The "palipsestuous relation" (see ibid., p. 14) can perfectly be applied to the superposition of codes in the present case. It is difficult, however, to affirm a unilateral "branchement". It is, of course, possible to state that the symbolic-esthetic "Oriental" code is "pluged" on a Western (Spanish) linguistic-graphematic code; however, there is no reason to deny that the latter code is simultaneously "pluged" on the further. This bilateral relation is precisely the basis of the interconnection of codes which is proper to the anthropological model of "branchement"; this interconnection permits, or even imposes the dialogical articulation of opposite identity poles subjected to a coevolutive reconfiguration.

Still in Jean-Loup Amselle's terms, we can observe a procedure corresponding to what he calls "décrochage" (Amselle 2008), but in its 'light' version. We take here the notion of "décrochage" in its multiple sense: on the one hand, it means a manoeuvre of appropriating the West; on the other hand, the West is dethroned, its hegemony expropriated, giving free way to the project of a civilizational counter-model. But here we are in presence of a 'light' postcolonial "décrochage" since the Western world's achievements, here in its Hispanic form, are not devalued, but selectively assimilated by symbolic procedures apt to articulate dialogically the historical differential poles in order to reshape and recompose a HispanoOriental identity.

The same structure of virtual quasi-detour via diachrony back to a deconstructed-reconstructed synchrony can be discerned in the textual document in articulation with the photo. The military confrontations during the prolonged colonial era appear clearly to be a part of the complex of deconstructed differences; this underlines the deeply rooted postcolonial character of this hispanophone media communication. Even war turns out to be an element susceptible to reconcile the adversaries, since it establishes a partly symmetric, partly asymmetric relation and leaves deep engrammes in the collective historical memory; this impacts widely on the organization of the oppositive diffential structure. The commemoration over the historical distance allows to emphasize with precision this link created by the historical conflict situation, which is here exploited as a symbolical resource for a (limited) convergence, corresponding to the above motto: i.e. to turn to the future by the bias of the look at the past. In this view, the differences between adversaries are minimized, the conflict appears as an unvoluntary accident: "A Franco le afectó mucho esta guerra [...] pues Mohamed V era como su hermano, él había realizado casi toda su carrera militar en África y la Guardia Mora era como su familia". The iconico-textual articulation points just into the same direction: We don't see a Moroccan independentist parachutist, but a Spanish veteran, ce-

\footnotetext{
${ }^{8}$ This convergence is not trivial. Many online documents on this website refer to the Sahara independence movement with the related links. This "South-South" relation of the Moroccan Hispanity is worth to be examinated; this aspect will have to be reserved to further investigations.

9 This is the reason for the presence of Tifinagh characters in the toponymic transliteration, cf. above $\S 2$.

${ }^{10}$ The Sidi Ifni region has been liberated from the Franquist colonial yoke as late as in 1969.
} 
lebrated like a hero: "El riojano José Luis González Vicente no sólo es uno de los supervivientes de la contienda sino que, además, participó en el único salto paracaidista llevado a cabo por el Ejército español en acto de guerra. El próximo domingo se cumplen 54 años." The former colonial adversary (diachrony) appears in the light of the present situation (synchrony) in a relation of complementarity and gains acceptance as an orientation model. The media-driven commemoration of historical difference by the use of the Spanish language turns out to be the vector for a - selective - Oriental convergence and modernization, and hence to be a newly 'relooked' Arabo-Islamic, and generally Oriental basis of identity. Our analysis puts in evidence that the processing of the "archetypal' "leading differences" are subjected by the media to a deconstructive evolution which is totally different from what we found in the North.

\subsection{Sahara}

The last document to be discussed in the present contribution (Annex 4) has been put online by the Western Sahara's movement for independence. The mediatisation of Spanish serves here as bridge of solidarity between Arabs. Indeed, Saharans are themselves Arabs (not Berbers), ${ }^{11}$ but they belong to the ethno-dialectal group of Hassaniyya. They have hence a special identity status towards the rest of Morocco (but also Algeria ...). The principal oppositive differential pole is here neither Europe nor the Western world, even less Spain, but the official Moroccan mainstream emanating from Rabat. The cultural and linguistic marks left in Sahara by the colonial era, and first of all the Spanish language, are now directed

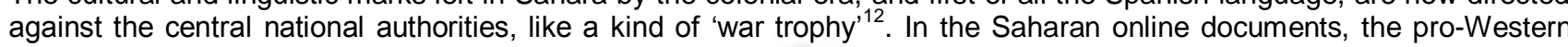
cultural, linguistic and political orientation is evident. We have to keep in mind, however, that the scene is still the Moroccan media landscape - at the condition that Sahara is recognized as a part of the Moroccan nation. ${ }^{13}$ It is well-known that Algeria is the first partner of the SADR against the Moroccan "occupation", and the seat of the Saharan exile government is based in Tindouf, on the Algerian territory. This support is certainly not independent of Algeria's interest in the abundant natural resources of Sahara. This is still the main stumbling block in the Algero-Moroccan diplomatic relations (cf. Delmote 2001). ${ }^{14}$ Spanish, and hispanophone presence in Algeria have, of course, a long tradition in Algeria; historically, Northern African hispanophony goes far beyond Morocco and represents a major pan-Maghrebi phenomenon, ${ }^{15}$ but today Morocco (with the "presidios") remains its last - rather weakened - bastion. The Algero-Moroccan partnership we see medialized in the present document can be considered a far echo of the historical diffusion of Spanish language in Maghreb. On this historical background we can define the celebrative function of Spanish by virtue of which the AlgeroSaharan alliance is welded and, in parallel, the inner-Arabic division between the latter and Morocco as a nation is deepened: "ha elogiado el papel", "aplaudió los esfuerzos de los medios de comunicación argelinos", "transmitir la voz del pueblo saharaui". Implicite assertive speech acts are here to be identified, because the discourse presupposes, of course, the existence of a Saharan people as ethnic and national entity; this is far from being recognized by all the actors on the national and international scene. This is the performative objective of Spanish language's celebrative function, which is attained by the implicite reference to a mythic past.

A look at the photo and the analysis of the iconico-textual articulation authorizes us to express some doubts about the solidity of this alliance represented in this Spanish media. The message of the photo is extremely neutral, even poor. The two persons, protagonists of the Algero-Saharan pact, seem to be pushed to the left and right margin of the photo. The centre of the photo does not contain any significant elements related to the text; on the contrary, it marks the physical distance between the two persons. Considering that physical distance is also a proxemic marker of social, psychological and affective distance, we can ask ourselves about the document's persuasive force concerning the Algero-Saharan solidarity. On the other hand, the doubts involontarily engendered by the document's semiotic organization make the celebrative formulas supposed to attest the inviolable alliance between Algeria and Western (i.e. Moroccan) Sahara appear even more necessary: by (over)compensation.

The historical and political context of Sahara and of its Hispanity goes here pari passu with another evolution of the systemic organization of the "leading differences". It appears indeed that the Arabic and "Oriental" oppositive pole is far from being one and indivisible. However, the new patterns of divisions and alliances which come to appearance at this pole seem to be unstable. In addition to that, an entity belonging a priori to one differential oppositive pole can be "pluged" on its primordial - here hispanophone/-phile and Western - "Other", in order to make front against one of its Arabian, respecttively Western 'enemy brothers'. The African perspective does not seem to play any role in here, but the new division inside the Arabo-Oriental 'camp' seem to impact the ethnic differences; however, they may also be insignificant if the historical and political context is favourable to such a denouement (for instance in the case of the convergence of Ifni and Sahara).

\section{SOME THEORETICAL CONCLUSIONS}

During our virtual journey across different zones of the (post)colonial Hispanity in North-Western Africa we could identify several historical, political, social, economic, cultural and sociolinguistic parameters motivating different structurations and

\footnotetext{
${ }^{11}$ A deepened analysis could, however, put in evidence the affinities between the Sidi Ifni and the Sahara Hispanity, independently from autochtone ethnic and linguistic affiliation and solidarity. The prolonged Spanish colonial era in both of the territories seems to play a role in here.

12 Think about the formula of "butin de guerre" coined by Kateb Yacine in respect of the case of French in Algeria.

13 Indeed, all the European countries (included Spain) do so. The only European country having recognized the SADR (Sahrawi Arab Democratic Republic) in the past is former Yougoslavia.

14 Cf. the Oujda document discussed in $\S 2.2$., Annex 2.

${ }^{15}$ For general information see Dakhlia (2004).
} 
restructurations, deconstructions and reconstructions of the "leading differences" to which the functioning of the internal logic of the observed media systems is subjected. What appears as contingency of the distinctive primordial choices related to the basic systemic functioning has hence a fundamentum in re which can be clearly identified in each case. In this respect, as the result of our analysis we can point out an evident North-South discrepancy: the North is the pole of conservation, whereas the South represents the core area of deconstructive evolution. In dependence of these parameters, the media systems proceed to the construction of their extrasystemic environment and, concomitantly, to the reproduction of their own intrasystemic identity.

Our analysis has allowed us to inspect the systemic "black boxes", and our contrastive method permitted us to put into evidence some of their functional principles. We could show how these principles are involved in the co-construction of the Same and the Other (extrasystemic environment observed from inside). From a postcolonial point of view, we have to emphasize that, and how, the choice of Spanish participates in the constructive modalities of the extrasystemic environments in interaction with the systemic functioning itself - each time from the system's internal perspective. With reference to McLuhan's (2001) well-known dictum, according to which the medium is the message, we can conclude: Very well. But if it is so, then the medium's code is the message, too.

\title{
4. ANNEXES: ONLINE DOCUMENTS
}

\section{Annex 1: Blog de Ceuta 2}

http://blogceuta2.blogspot.com/2010/10/ame-advierte-de-la-amenaza-islamista-en.html

\section{BLOG DE CEUTA 2}

\author{
www.blogdeceuta.com
}

- $\quad$ Página principal

AME advierte de la amenaza islamista en Ceuta y Melilla y pide "cautelas tremendas" para los militares extranjeros

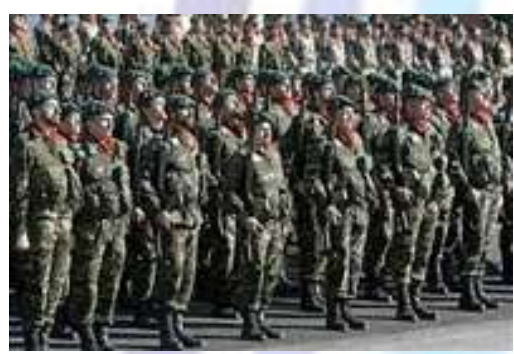

\section{fuente : EUROPA PRESS}

MADRID, 5 Oct. (EUROPA PRESS) -

El presidente de la Asociación de Militares Españoles (AME), Leopoldo Muñoz Sánchez, ha advertido de "la amenaza del mundo islámico contra occidente" en Europa, incluido en "sitios concretos y localizados como Ceuta y Melilla y que no están amparados por la OTAN", y ha subrayado la necesidad de que se apliquen "cautelas tremendas" para los militares extranjeros y particularmente de religión musulmana y, ante todo, "evitar otra reconquista" musulmana del territorio español.

"Es un peligro real y cierto", ha recalcado durante una conferencia en el Centro Cultural de los Ejércitos, preguntado por la supuesta existencia de "una quinta columna" en el Ejército español en las ciudades autónomas.

Muñoz Sánchez ha insistido en la necesidad de que los militares extranjeros sean destinados "donde deben ir" y "además con un as cautelas tremendas" para evitar que puedan "superponer la condición por sentimiento religioso a su obediencia a las leyes de la nación a la cual han prometido o jurado". "Está claro que el conflicto que hay no va a ser de unidad de divisiones contra divisiones, sino de terrorismo", ha explicado.

"Deben de estar sujetos a las leyes disciplinarias españolas. Todo aquél del que de algún modo se sospeche o confiese que no lo está, habrá que cambiarlo", ha insistido en declaraciones a Europa Press al término de la Conferencia.

El presidente de la AME ha recordado que los islamistas radicales creen que "Al Andalus es toda la Península lbérica" y por tanto la consideran "territorio ocupado". "No es solamente Ceuta y Melilla, y cuando digo la Península Ibérica incluyo Portugal", ha explicado en su intervención ante una veintena de militares. "Lo malo es otra reconquista. Hay que evitarlo", ha insistido el militar.

Tras recordar que las autoridades estadounidenses como las francesas han advertido de "posibles atentados en Europa", ha advertido del peligro de la infiltración de islamistas, citando el "ejemplo" de los dos guardias civiles y de su traductor, asesinados a finales de agosto por un insurgente "chofer del jefe" de la Policía afgana que trabajaba con los españoles y que se infiltró en la antigua base española en Qala-i-Now.

Por otra parte, el presidente de AME ha adelantado que su asociación ha concluido "un anteproyecto de Ley de Personal Militar" que tiene intención de presentar el mes de noviembre como posible sustitución de la Ley de Carrera Militar, aprobada en 2007. Muñoz Sánchez ha defendido la necesidad de que dicho proyecto de ley deje "perfectamente contemplado" las "cautelas" que se deben aplicar a los militares extranjeros y también ha defendido que el anteproyecto de ley que han elaborado persigue, entre otros objetivos, la creación de una fuerza de reserva "obligatoria" y mejorar y facilitar la promoción interna en todas las escalas.

AME también considera necesario "que desaparezca la Unidad de Emergencias Militares" al considerar que las tropas sólo deben intervenir en caso de incidentes o desastres naturales como los terremotos "cuando la sociedad civil se vea desbordada" para hacer frente a ellos.

Publicado por Blog de Ceuta en 13:21

Etiquetas: AME advierte de la amenaza islamista en Ceuta y Melilla y pide "cautelas tremendas" para los militares extranjeros 


\section{Annex 2: La gente invisible de Ujda}

http://amnistia.me/profiles/blogs/la-gente-invisible-de-ujda

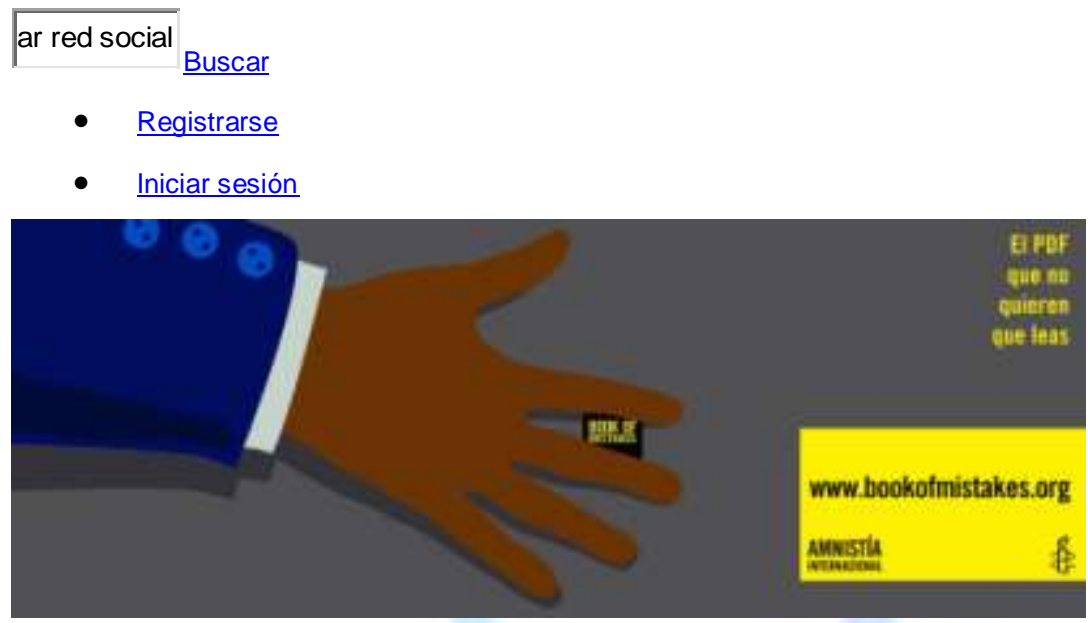

- $\quad$ Amnistía

- $\quad$ Mi Perfil

- $\quad$ Noticias

- Unete a Al

- $\quad$ Contacto

- Miembros y Redes

- Blogs

\section{Activistas de Amnistía Internacional Venezuela}

Apoya la Campaña Basta de Balas
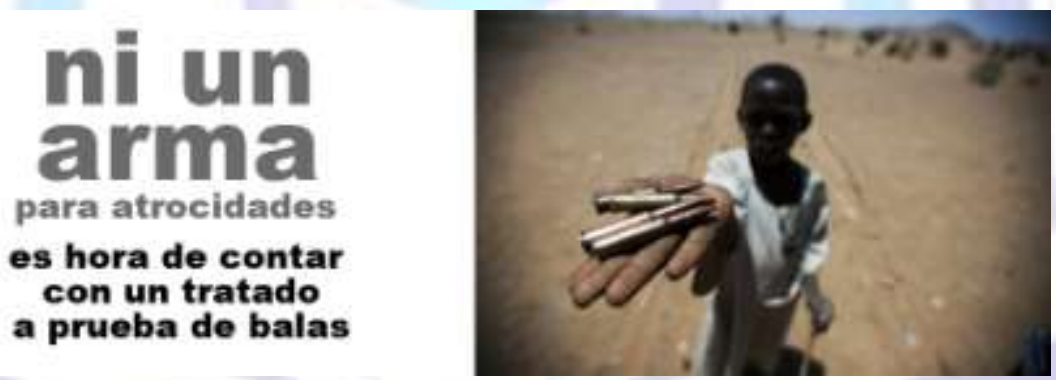

- Todos los Posts en Blogs

- $\quad$ Mi Blog

- $\quad$ Agregar

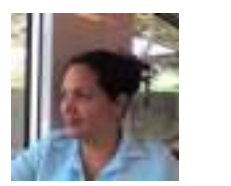

La gente invisible de Ujda

- Publicado por alejandra rodriguez en 12 / 04 / 2011 a la(s) 3:35pm

- $\quad$ Ver blog

Durante las últimas tres décadas, los gobiernos europeos han llevado a cabo una campaña cada vez más 
despiadada para evitar que los inmigrantes sin papeles crucen o incluso alcancen sus fronteras. En los últimos años, la ciudad de Ujda, en el noreste de Marruecos, se ha convertido en uno de los muchos lugares en lo que esta obsesión ha tenido consecuencias nefastas.

Extracto de un artículo publicado en The New York Times.

La importancia de esta moderna y bulliciosa ciudad de 500.000 habitantes a sólo 15 kilómetros de la frontera argelina en las guerras fronterizas de Europa se debe en parte a su ubicación estratégica en la vía migratoria que cruza a través del Sáhara hasta Malí, Níger, Nigeria e incluso más allá. Desde 1994 la frontera de Ujda está cerrada por razones políticas, pero para muchos inmigrantes que cruzan el Sáhara, sigue siendo una escala decisiva que los deja más cerca de la tierra prometida de Europa.

Ujda está a sólo unos 150 kilómetros de la ciudad costera de Melilla, pero para la policía y las fuerzas de seguridad marroquíes, su cercanía al desierto la convierte en el lugar idóneo para deportar a inmigrantes detenidos en otros puntos del país. En realidad, Ujda se ha convertido en un microcosmos de un fenómeno de mayor alcance, en el que los sueños de los inmigrantes se topan con la implacable maquinaria de la Fortaleza Europa.

En otoño de 2005, miles de africanos subsaharianos fueron deportados a este lugar y abandonados en el desierto sin comida ni agua tras un intento en masa de escalar las vallas fortificadas que rodean a las ciudades españolas de Ceuta y Melilla, en el norte de Marruecos. Muchos murieron antes de que el gobierno marroquí cediera y llevara a cabo una operación de rescate.

La respuesta de la Unión Europea a estos impactantes sucesos fue reforzar sus fronteras meridionales, dejando varados en Marruecos a cerca de 10.000 inmigrantes, según algunos cálculos. Aproximadamente 700 de ellos viven en Ujda o los alrededores.

....

Los hombres, mujeres y niños inmigrantes viven en la pobreza más absoluta. Los destartalados campamentos son con frecuencia objeto de redadas de la policía, que deporta a sus habitantes al borde del desierto, donde es muy probable que los violen y ataquen los bandidos o que los guardas de la frontera argelina los hagan volver en lo que equivale a un despiadado juego de ping-pong con humanos.

"Aquí vivimos como conejos", explica un joven nigeriano llamado Anthony. "Nos escondemos de día y salimos por al noche". Algunas personas llevan años viviendo de esta manera.

En uno de los campamentos conocía a una mujer congoleña llamada Dolita que abandonó Kinshasa, República Democrática del Congo, para pedir asilo en Europa. Hace dos meses la deportaron al desierto con sus tres hijos, incluido un bebé recién nacido. Sólo se salvó gracias a un tenaz defensor de los derechos humanos, Hicham Baraka.

En teoría, los gobiernos europeos cuyas políticas han creado esta desgracia humana deberían hacer un esfuerzo para garantizar que son tratados con humanidad y respeto, pero Europa guarda silencio. $Y$ al igual que a los inmigrantes de las chabolas arrasadas de Calais, Francia, y Patmos, Grecia, a los apátridas de Ujda se les está administrando un severo tratamiento para curarlos de sus sueños europeos.

\section{Annex 3: El rincón de Sidi Ifni}

http://www.sidi-ifni.com/index.php?option=com_frontpage\&ltemid=1

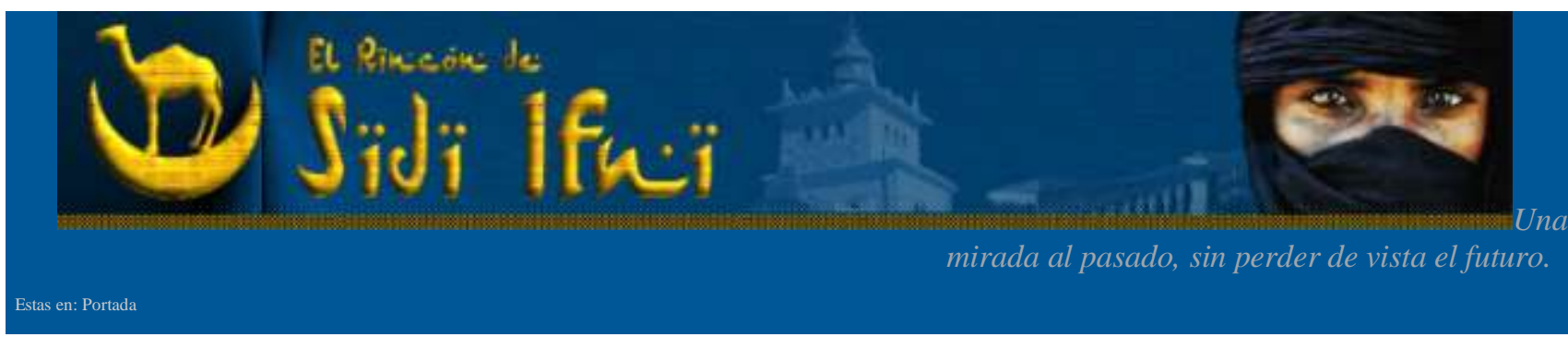

\section{Ifni, la querra que Franco ocultó}

En la noche del 23 de noviembre de 1957, un grupo de guerrilleros marroquíes, organizado por el príncipe Muley Hasan, que pronto se convertiría en Hasan II, atacó Sidi Ifni, la capital de la colonia que España defendía en el sur de Marruecos. La Guerra de Ifni estalló, para sorpresa del general Franco, castigando a unas tropas que custodiaban las colonias del 
norte de África con más voluntad que medios. El riojano José Luis González Vicente no sólo es uno de los supervivientes de la contienda sino que, además, participó en el único salto paracaidista llevado a cabo por el Ejército español en acto de guerra. El próximo domingo se cumplen 54 años.

Tras lograr la independencia en 1956, Marruecos comenzó a movilizarse para conseguir la descolonización de las posesiones españolas. Si el sultán Mohamed V alentó a los conspiradores del Ejército de Liberación Marroquí en Ifni, su hijo Hasan lo apoyó con armas y dinero. La situación de las tropas españolas era lamentable. Apenas tenían armamento ni munición ni transporte, los soldados hacían la instrucción en alpargatas compradas en el zoco de Sidi Ifni, la capital, y los puestos de control repartidos por el territorio, poco más de un tercio de La Rioja (1.500 kilómetros cuadrados), apenas eran unas casetas de tejavana sin condición alguna.

Cuando los rebeldes generalizaron su ofensiva, los puestos de vigilancia apenas pudieron plantar cara. Muchos militares españoles murieron, otros fueron torturados, aunque muchos de ellos resistieron hasta la extenuación.

«Primero la Legión y luego la Brigada Paracaidista fuimos al rescate y liberamos a muchos de los que estaban atrapados. Ganamos la guerra desde la perspectiva militar pero no volvimos todos. En total, en las operaciones de guerra de Ifni y el Sáhara murieron 152 militares, 50 fueron dados por desaparecidos y y otros 518 resultaron heridos, según fuentes oficiales de la Capitanía General de Canarias», explica González Vicente.

\section{La reconquista española}

En febrero de 1958, las tropas españolas apoyadas por las francesas comenzaron la reconquista frente al Ejército de Liberación Sahariano, operación en la que participó en paracaidista riojano. El poder absoluto hispano-francés del espacio aéreo dio sus frutos, tras el despliegue de 130 aviones (60 españoles y 70 franceses), al tiempo que por tierra llegaban 9.000 soldados españoles y 5.000 franceses.

A José María Ezquerro, un joven zapador de Pradejón, la guerra le tocó en Tetuán. «Nos enviaron al Aaiún y allí estuve en las trincheras protegiendo el aeropuerto -recuerda-. Fueron momentos muy malos, sobre todo el 13 de enero de 1958 en el que tuvimos 44 muertos. Por el día hacía un calor insoportable y por la noche te helabas de frío. No teníamos ni ropa adecuada ni armas ni comida». Fueron siete meses «horribles» para este riojano que hoy tiene 76 años. «Nunca he vuelto allí ni ganas que tengo de volver».

Por fin, el 1 de abril de 1958 fueron rubricados los acuerdos de Cintra entre los gobiernos de Madrid y de Rabat, por los que España entregaba a Marruecos la zona de Cabo Juby, entre el río Draa y el paralelo 27ํㅜㅇ', aunque quedaba excluida la capital, Sidi Ifni, así como el resto del Sáhara Occidental.

«A Franco le afectó mucho esta guerra -argumenta González Vicente-, pues Mohamed V era como su hermano, él había realizado casi toda su carrera militar en África y la Guardia Mora era como su familia. Nunca pudo digerir la traición». Y añade: «La Guerra de Ifni la ganamos los españoles desde la perspectiva militar, pero después Ifni se entregó a Marruecos de forma vergonzosa y se ocultó a la gente».

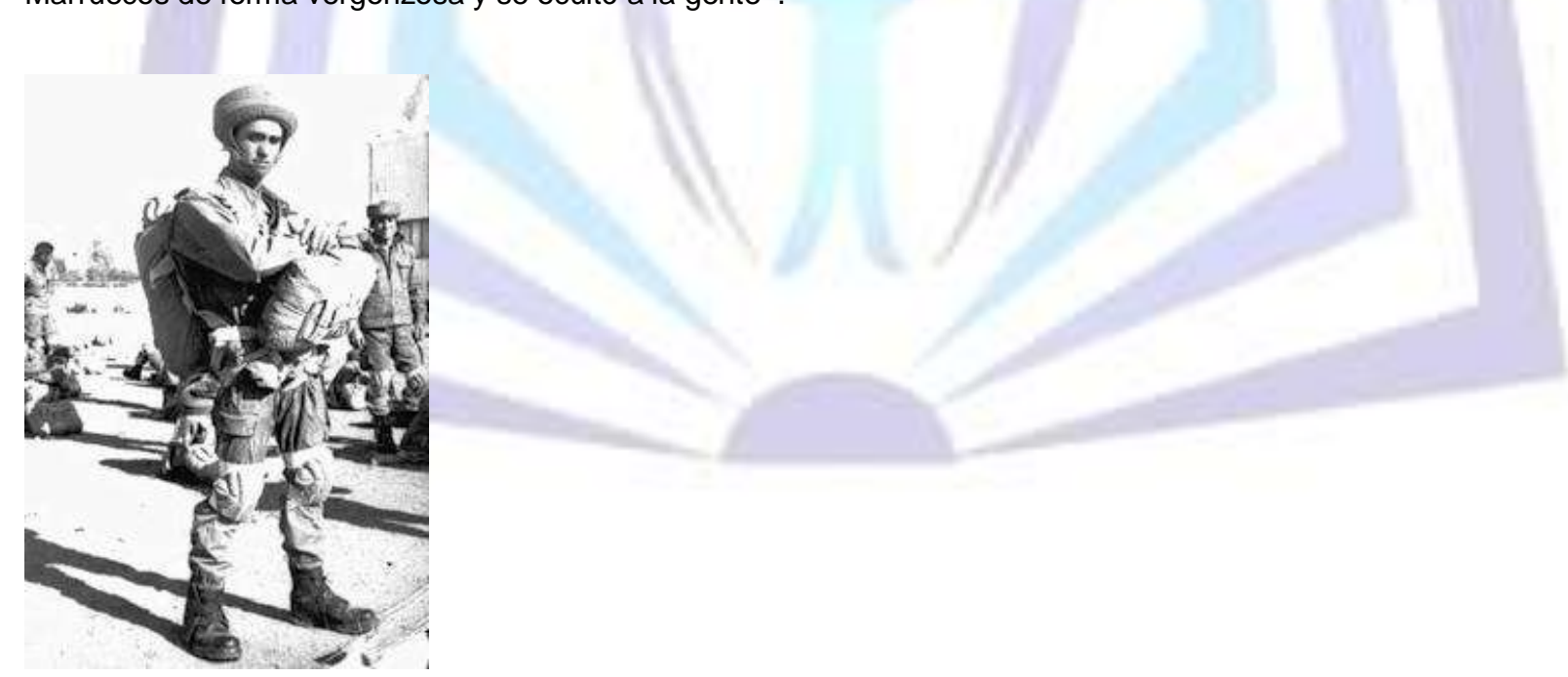

\section{Annex 4: SPSRASD (Sahara)}

http://www.spsrasd.info/es/content/embajador-saharaui-en-argelia-elogia-labor-de-los-medios-de-informaci\%C3\%B3nargelinos-en-la-defe

\section{Embajador saharaui en Argelia elogia labor de los medios de información argelinos en la defensa de la causa saharaui}

Mar, 27/03/2012 - 17:04 Tags: 


\section{- Sahara Occidental}

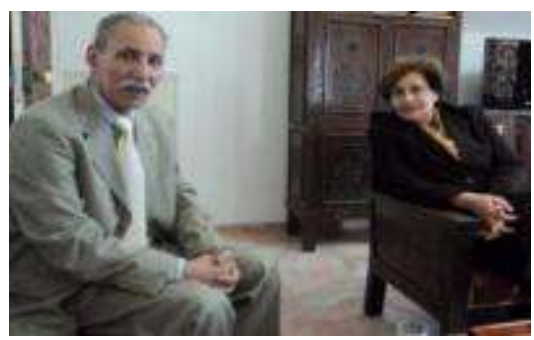

Argel,27/03/12 (SPS) -.El Miembro del Secretariado Nacional del Frente Polisario y embajador de la RASD en Argelia, Brahim Ghali, ha elogiado el papel del diario argelino "Shaab" (el pueblo) en la sensibilización de la opinión pública nacional e internacional sobre la lucha de pueblo saharaui, durante una visita este lunes a la sede del periódico con motivo del nombramiento de su nuevo director.

Embajador Ghali, aplaudió los esfuerzos de los medios de comunicación argelinos para transmitir la voz del pueblo saharaui durante una reunion del diplomático saharaui con el equipo del diario Shaab. (SPS) 090/099 TRAD

\section{REFERENCES}

[1] Amselle, J.-L., 2001, Branchements. Anthropologie de l'universalité des cultures. Paris, Flammarion.

[2] Amselle, J.-L., 2008, L’Occident décroché. Enquête sur les postcolonialismes. Paris, Stock.

[3] Bennani-Chraïbi, M., 1994, Soumis et rebelles: les jeunes au Maroc. Paris, CNRS Editions.

[4] Berghaus, M., 2011, Luhman leicht gemacht. $3^{\text {rd }}$ ed., Cologne, Weimar, Vienna, Böhlau Verlag.

[5] Dakhlia, J., ed., 2004, Trames de langues. Usages et métissages linguistiques dans l'histoire du Maghreb. Paris, Maisonneuve \& Larose.

[6] Delmote, G., 2001, Ponts et frontières entre Espagne et Maghreb. Paris, L'Harmattan.

[7] Feustel, R. and Schochow, M., eds., Zwischen Sprachspiel und Methode. Perspektiven der Diskursanalyse. Bielefeld, transcript Verlag.

[8] Fuchs, P., 2004, Niklas Luhmann - beobachtet. $3^{\text {rd }}$ ed., Wiesbaden, VS Verlag für Sozialwissenschaften.

[9] Jablonka, F., 2009, L'arabophonie au Maroc et la francophonie "branchée". Aspects ethno-sociolinguistiques de l'interculturel, Romanistisches Jahrbuch 60, 64-83.

[10] Jablonka, F., 2012, Vers une socio-sémiotique variationniste du contact postcolonial: le Maghreb et la Romania européenne. Vienna, Praesens.

[11] Luhmann, N., 1988, Soziale Systeme. Grundriss einer allgemeinen Theorie. $2^{\text {nd }}$ ed., Francfort/M., Suhrkamp.

[12] Luhmann, N., 2009, Die Realität der Massenmedien. $4^{\text {th }}$ ed., Wiesbaden, VS Verlag für Sozialwissenschaften.

[13] McLuhan, M., 2001, Understanding Media. $2^{\text {nd }}$ ed., London, Routledge.

[14] Said, E. 1978, Orientalism. Western Conceptions of the Orient. London, New York, Penguin Books.

[15] Sarasin, Ph., 2003, Geschichtswissenschaft und Diskursanalyse. Francfort/M., Suhrkamp.

[16] Schmidt, S.J., ed., 1992, Kognition und Gesellschaft. Der Diskurs des Radikalen Konstruktivismus 2. Francfort/M., Suhrkamp.

[17] Schmidt, S.J., 1994, Kognitive Autonomie und soziale Orientierung. Konstruktivistische Bemerkungen zum Zusammenhang von Kognition, Kommunikation, Medien und Kultur. Francfort/M., Suhrkamp.

[18] Spencer Brown, G., 2008, Laws of Form. Leipzig, Joh. Bohmeier.

[19] Torterat, F., forthcoming 2013, Quand la voie que prend la ville passe par la confrontation des voix (et donc des points de vue): l'exemple de la blogosphère politique. In Jablonka, F., ed., Voies des villes - voix des villes. Dimensions postcoloniales. Proceedings of the International Colloquium, Amiens, january 12th - 13th, 2012., Paris, L'Harmattan. 


\section{Author' biography with Photo}

Born in Gelsenkirchen (Western Germany); studies in Münster, Turin and Paris (Dauphine); Master of Arts 1991 in General Linguistics, Romanance Philology and Philosophy, Münster 1991; Ph.D. and Habilitation in Romance Linguistics, Bremen 1997 and Vienna 2013; researcher at the Universities of Vienna and Amiens; main research interest: sociolinguistics of variation in language contacts

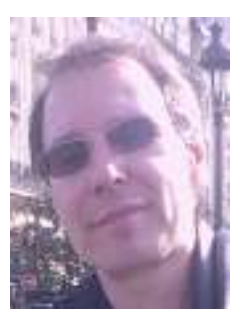

